\title{
Description of Transformational Leadership Style and Professionalism of Lecturers of Private Universities in Indonesia
}

\author{
Ratna Koba Susanti ${ }^{1}$, Anwar Sanusi ${ }^{2}$, Harsono ${ }^{3}$ \\ ${ }^{1-3}$ University Of Merdeka Malang
}

Indonesia

\begin{abstract}
Lecturers are one of the essential components of the higher education system in Indonesia. The roles, duties, and responsibilities of lecturers are critical in realizing national education goals, namely educating the nation's life and improving the quality of Indonesian human resources. The quality of human resources in question includes faith/taqwa, noble character, mastery of science, technology, and art, in realizing an advanced, just, prosperous, and civilized Indonesian society. Lecturers are required to be able to show good performance. Lecturer Research Sample The sample size was determined by using the Slovin formula of 150. Based on Table 7, it can be seen that from the distribution of respondents' answers about the leader must be friendly to subordinates, the majority of the answers agreed with as many as 91 respondents (60.7\%), although there were $1(0$, 7\%) of respondents who said they did not agree. The average score obtained is 4.03, indicating that respondents agree that leaders must always be friendly to subordinates, both lecturers and employees. The distribution of respondents' answers to the leader having good communication with subordinates shows that most of the respondents agree as many as 88 respondents (58.7\%), although two respondents (1.3\%) disagree. The average score of 4.03 shows that respondents agree with leaders who have good communication with subordinates. The results showed that the transformational leadership style was formed from idealized influence: inspirational motivation, intellectual stimulation, and individual consideration. The most significant contribution to the formation of a transformational leadership style is idealized influence, which is reflected in the leader must have extensive knowledge. Professionalism formed from Pedagogic Competence.
\end{abstract}

Keywords: Transformational Leadership Style, Lecturer.

\section{INTRODUCTION}

According to the Law of the Republic of Indonesia, Number 14 of 2005 concerning Teachers and Lecturers defines that lecturers are professional educators and scientists with the main task of transforming, developing, and disseminating science, technology, arts through education, research, and community service. Based on this understanding, the lecturer has a vital role in implementing the entire educational process. Moreover, lecturers are responsible for the teaching and learning process as the main component, therefore to improve the quality of higher education, lecturers play a crucial role and position in the entire educational process, especially in higher education.

Lecturers are one of the essential components of the higher education system in Indonesia. The roles, duties, and responsibilities of lecturers are critical in realizing national education goals, namely educating the nation's life and improving the quality of Indonesian human resources. The quality of human resources in question includes faith/taqwa, noble character, mastery of science, technology, and art, in realizing an advanced, just, prosperous, and civilized Indonesian society. Therefore, lecturers are required to be able to show good performance.

Lecturer performance is critical and an indicator of the success of higher education. The results achieved must be by the established indicators, not only based on internal campus indicators or the independence of lecturers, but also other required indicators. Not only that, but the performance of lecturers also refers to the achievement of the implementation of the Tri Dharma of Higher Education such as minimum education and so on. As is known, Based on the Minister of Administrative Affairs Regulation Number 17 of 2013 as a follow-up to Law Number 14 of 2005 concerning teachers and lecturers, the minimum requirement as a lecturer is a Master's degree.

This is intended so that lecturers have more knowledge than the students being taught; with increased knowledge and expertise, it will increase self-confidence as a lecturer; with high confidence, it is hoped that their performance will also be good. Performance is achieved or demonstrated achievement or ability to work; in other words, that performance can be interpreted as 
work performance. If performance is the quantity and quality of work completed by individuals, then performance is the task execution output. Performance can also be interpreted as the work performance shown by someone related to their duties or workability as a result of work morale, which is shown in behavior. Therefore, lecturer performance can be defined as workability or work performance which is the culmination of work morale results shown by lecturers in carrying out their duties on campus.

Based on the background above, the problem can be formulated: How to describe the Professionalism Leadership Style and Work Discipline of Private Higher Education Lecturers (PTS) at the Higher Education Service Institute-East Java. Private sector (PTS) in higher Education Service Institutions East Java. The research contribution is for the leadership of private universities in the East Java Higher Education Service Institute, the object of research, which is expected to contribute ideas about managerial practices in managing lecturer performance improvement.

\section{LITERATURE REVIEW}

The transformational leader stimulates and inspires (changes) followers to achieve extraordinary results. Transformational leaders inspire their followers to put aside their interests for the organization's good, and they can have a tremendous influence on their followers. (Robbins, 2008: 90). Transformational leadership is more than charismatic leadership because transformational leaders try to instill in followers the ability to question established views and the views held by the leader. In addition, leaders pay attention to the needs, concerns, and development of individual followers, change followers' awareness of problems by helping them to see old problems in new ways, and they can arouse and inspire followers to put out extra effort in achieving group goals (Robbins, 2012; 497).

Transformational leadership, namely leadership, provides individual attention and intellectual stimulation and has charisma. Transformational leadership calls for more on the moral values of followers to increase their awareness of ethical issues Rorimpandey, (2013: 237). Transformational leadership is a leader who devotes his attention to the problems faced by his followers and the development needs of each of his followers by providing enthusiasm and encouragement to achieve his goals. Transformational leadership is leadership where the leader motivates his subordinates to do more than initially expected by increasing the importance of subordinates and the value of the importance of work. Transformational leaders can make their subordinates aware of a broader perspective so that individual interests will be subordinated to the interests of the team, organization, or other broader interests. Hariyanti (2011:45) argues that transformational leadership is leadership in which the leader motivates his subordinates to do more than initially expected by increasing the importance of subordinates and the value of the importance of work. Transformational leadership is leadership where the leader provides individual attention, intellectual stimulation and the leader has charisma. The indicators are: a) charisma; Providing vision and mission to gain respect and trust, b) Inspiration; Communicating high expectations, simply expressing the importance of goals, c) Intellectual Stimulation; Encouraging intelligence, rationality, and caution in solving problems, d) Individualized Consideration; Giving personal attention, training, giving advice Wijayanto (2012:176).

Some understanding of transformational leadership style according to the experts above, it can be concluded that transformational leadership style is a leadership style that can unite all individuals and change the beliefs, attitudes, and personal goals of each subordinate to achieve goals beyond the goals set. The leader will motivate subordinates by responding to the needs of subordinates related to competency empowerment and adjusting the goals and targets of subordinates individually, in groups, and in organizations, which has an impact on subordinates' confidence in the abilities of their leaders to increase subordinates' confidence, emotional involvement, and motivation to improve performance targets.

Table 1. Previous Research for each variable

\begin{tabular}{|c|c|c|c|c|}
\hline No. & $\begin{array}{c}\text { Researcher } \\
\text { (years) }\end{array}$ & $\begin{array}{c}\text { Research Variables } \\
\text { Research }\end{array}$ & Results & Similarities and differences \\
\hline 1. & $\begin{array}{l}\text { Anung } \\
\text { Pramudya } \\
(2010)\end{array}$ & $\begin{array}{l}\text { Motivation, competence, } \\
\text { leadership and work } \\
\text { environment } \\
\text { andperformance }\end{array}$ & $\begin{array}{l}\text { leadershipaffect } \\
\text { performance }\end{array}$ & $\begin{array}{l}\text { Similarity: } \\
\text { Examines lecturer performance. } \\
\text { The difference: } \\
\text { I am not researching } \\
\text { transformational leadership } \\
\text { style, professionalism, and work } \\
\text { discipline. }\end{array}$ \\
\hline 2. & $\begin{array}{l}\text { Hilma Harmen } \\
\text { and Dita } \\
\text { Amanah (2013) }\end{array}$ & $\begin{array}{l}\text { Organizational } \\
\text { Commitment and } \\
\text { Performance }\end{array}$ & $\begin{array}{l}\text { There is a positive } \\
\text { relationship between } \\
\text { professionalism and } \\
\text { performance, } \\
\text { organizational }\end{array}$ & $\begin{array}{l}\text { Similarity: } \\
\text { Researching professionalism, } \\
\text { organizational commitment, and } \\
\text { performance }\end{array}$ \\
\hline
\end{tabular}


International Journal of Advances in Scientific Research and Engineering (ijasre), Vol 7 (9), September -2021

\begin{tabular}{|c|c|c|c|c|}
\hline No. & $\begin{array}{l}\text { Researcher } \\
\text { (years) }\end{array}$ & $\begin{array}{c}\text { Research Variables } \\
\text { Research }\end{array}$ & Results & Similarities and differences \\
\hline \multirow{3}{*}{3.} & & \multirow{3}{*}{$\begin{array}{l}\text { Transformational } \\
\text { leadership } \\
\text { style,motivation } \\
\text { lecturer performance }\end{array}$} & $\begin{array}{l}\text { commitment, and } \\
\text { performance. } \\
\text { Professionalism and } \\
\text { organizational } \\
\text { commitment have a } \\
\text { positive effect on } \\
\text { performance }\end{array}$ & $\begin{array}{l}\text { Differences: } \\
\text { Not examining transformational } \\
\text { leadership styles and work } \\
\text { discipline }\end{array}$ \\
\hline & $\begin{array}{l}\text { Lestari } \\
\text { Makmuriana, } \\
\text { Usman }\end{array}$ & & $\begin{array}{l}\text { There is a positive } \\
\text { relationship between } \\
\text { transformational }\end{array}$ & $\begin{array}{l}\text { Similarity: } \\
\text { Examining lecturer performance }\end{array}$ \\
\hline & $\begin{array}{l}\text { Radiana, } \\
\text { Marmawi } \\
(2014)\end{array}$ & & $\begin{array}{l}\text { leadership style with } \\
\text { lecturer performance. }\end{array}$ & $\begin{array}{l}\text { The difference: } \\
\text { Does not examine } \\
\text { professionalism, work discipline, } \\
\text { and organizational commitment }\end{array}$ \\
\hline
\end{tabular}

\section{METHOD}

\section{Population}

The population in this study are permanent lecturers of private higher education foundations in the form of universities that have accreditation $\mathrm{C}$ and are not accredited in the Institutional Environment East Java Higher Education Services as many as 3579 people.

\section{Sample}

Lecturer Research Sample The sample size is determined by using the formula Slovin, Umar (2004:87), as follows :

$$
n=\frac{N}{1+N(e)^{2}}
$$

Information:

$\mathrm{n}=$ Number of Samples

$\mathrm{N}=$ Total Population

$\mathrm{e}=$ Percentage of allowance for the inaccuracy (precision) due to sampling error that can still be tolerated (8.00\%).

With $\mathrm{N}=3,594$, based on this formula, it can be determined that the number of samples in this study $=$

$$
\begin{gathered}
3,579 \\
\left(1+3,579(0,08)^{2}\right.
\end{gathered}
$$

Is rounded up to $=150$ people. The technique sampling at each existing PTS becomes the population determined by the proportional random sampling method. Operational Definition of Variables, Referring to the conceptual definition of these variables, the following will describe the indicators to be studied : A transformational leadership style in which the leader provides individual attention, intellectual stimulation, and the leader has charisma; the indicators are (1) Charisma; Giving vision and mission to gain respect and trust, (2) inspiration; Communicating high expectations, expressing the importance of goals in a way simple, (3) Intellectual stimulation; encouraging intelligence, rationality, and caution in solving problems, (4) Individualized consideration; Giving attention to personal, train, give advice.

Professionalism is a person's attitude or behavior in doing a particular profession. In a general sense, a person is said to be professional if he meets the criteria, namely having the expertise to carry out tasks according to his field, carrying out tasks by setting standard standards in his field, and carrying out the established profession. Indicators to measure this variable include: Pedagogic Competence $\left(\mathrm{X}_{2.1}\right)$, Professional Competence $\left(\mathrm{X}_{2.2}\right)$, Personality Competence $\left(\mathrm{X}_{2.3}\right)$, Social Competence $\left(\mathrm{X}_{2.4}\right)$ 


$$
r_{x y}=\frac{\left.n\left(\sum X Y\right)-\left(\sum X\right) \unrhd Y\right)}{\sqrt{\left\{n \sum X^{2}-\left(\sum X\right)^{2}\right\}}\left\{n \sum Y^{2}-\left(\sum Y\right)^{2}\right\}}
$$

Information:

$\mathrm{r}=$ Correlation Coefficient

$\mathrm{X}=$ Item score

$\mathrm{Y}=$ Total item score

$\mathrm{n}=$ number of respondents sample

with the following conditions:

if $r$ count is positive, and $r$ count $>r$ table 0.05 , the item or the variable is valid, if $r$ count is not positive (negative), and $r$ count $<\mathrm{r}_{\text {table }} .05$, then the item or variable is invalid, Santoso (2000:203)

\section{Reliability Test}

Instrument reliability analysis shows whether the instrument can measure something that is measured consistently over time. A measure is said to be reliable if it gives consistent results. Reliability was measured using the Cronbachmethod alpha. If the Cronbachvalue alpha is more significant than 0.6 (Alpa > 0.6), then it is said to be reliable (Sekaran, 2000).

$$
\alpha=\frac{2\left[S_{X}^{2}-\left(S_{y 1}^{2}+S_{y 2}^{2}\right)\right]}{S_{X}^{2}}
$$

Where:

$\mathrm{S}_{\mathrm{y}}{ }^{2}=$ Variance of subject scores in hemispheres 1 and 2

$\mathrm{S}_{\mathrm{x}}{ }^{2}=$ Variancescore subject to the overall test

$\alpha=$ Alpha reliability coefficient

is provided that:

If $\mathrm{r}$ is alpha positiveandr $>$ alpha $\mathrm{r}_{\text {table } \alpha 0.05}$, item or variable is reliable. If $\mathrm{r}$ is alpha positive and alpha $\langle\mathrm{r}$ table $\alpha 0.05$, item or variable is unreliable. (Santoso: 2000).

\section{RESULT}

\section{Validity and Reliability}

Data were analyzed in this study as the result of a questionnaire distributed to 150 respondents. To ensure the accuracy and consistency of the data subject of the study, the research questionnaire or point statement used will be tested first for validity and reliability.

a. Validity Test

A questionnaire as a measuring tool is declared consistent if measuring something repeatedly gives the same or consistent results. Measurement of the validity of this instrument is done by using a non-parametric correlation Spearman between item scores and scale scores. Overall the results of testing the validity of each variable can be seen in Table 5:

Based on the 86 statement items tested, all of them have a significant correlation coefficient value, indicated by the correlation probability value less than $=5 \%$, meaning that the questionnaire statement used is valid so that the instrument can be used to measure the variables of Transformational Leadership Style, Professionalism, Work Discipline, Organizational Commitment, and Lecturer Performance.

b. Reliability Test

Reliability using Cronbach's Alpha, in total, is presented in Table 6: 
International Journal of Advances in Scientific Research and Engineering (ijasre), Vol 7 (9), September -2021

Table 2. Value Cronbach's Alpha of Each Variable

\begin{tabular}{lccc}
\hline \multicolumn{1}{c}{ Variable } & AlphaValue & r Table & Description \\
\hline Transformational Leadership Style $\left(\mathrm{X}_{1}\right)$ & 0.913 & 0.1603 & Reliable \\
Professionalism $\left(\mathrm{X}_{2}\right)$ & 0.920 & 0,1603 & Reliable \\
Work Discipline $\left(\mathrm{X}_{3}\right)$ & 0.935 & 0.1603 & Reliable \\
Organizational Commitment $\left(\mathrm{Y}_{1}\right)$ & 0.911 & 0.1603 & Reliable \\
Lecturer Performance $\left(\mathrm{Y}_{2}\right)$ & 0.919 & 0.1603 & Reliable \\
\hline
\end{tabular}

Source: Primary data processed, 2021

Based on the reliability test and validity test results in Table 6, it is shown through Cronbach's Alpha with a value of more than 0.1620 so that all the questions used in the study are reliable and feasible to be used in data collection.

\section{Results of Descriptive Analysis Descriptive}

Analysis of variables in the study was carried out to obtain an overview of the tendencies or tendencies of respondents' assessment of the research variables consisting of the Transformational Leadership style. (X1), Professionalism (X2), Work Discipline (X3), Organizational Commitment (Y1), Lecturer Performance (Y2). Then do the calculation of the frequency distribution and the average (mean) number of respondents' answers.

\section{a. Description of Transformational Leadership Style Variables (X1)}

Variable indicator Transformational leadership style as in the measured table on four indicators: idealized influence, Inspirational Motivation, Intellectual Stimulation, and Individual Consideration. The frequency distribution of the Transformational Leadership style variable is obtained from the results of the tabulation of the respondents' answer scores as presented in Table 7.

Based on Table 7, it can be seen that from the distribution of respondents' answers about the leader must be friendly to subordinates, the most answers agree as much as 91 respondents $(60.7 \%)$, although there are $1(0.7 \%)$ respondents who disagree. Thus, the average score obtained is 4.03 , indicating that respondents agree that leaders must always be friendly to subordinates, both lecturers and employees.

The distribution of respondents' answers to the leader having good communication with subordinates shows that most of the respondents agree as many as 88 respondents $(58.7 \%)$, although two respondents $(1.3 \%)$ disagree. In addition, the average score of 4.03 indicates that respondents tend to agree with leaders who have good communication with subordinates.

The distribution of answers about leaders who have excellent attention to subordinates agrees with 90 respondents (60\%). However, two respondents disagree. Nevertheless, the average score of 3.99 shows that most respondents agree that the leader has a deep concern for subordinates.

The distribution of answers about the leader has a good personality. Most of the answers agree that 81 respondents (54\%). The average score of 3.83 indicates that most respondents tend to agree that the leader has a good personality.

The distribution of answers about leaders who have extensive knowledge agrees with 80 respondents $(53.3 \%)$. The average score of 4.09 indicates that most of the respondents agree that the leader has extensive knowledge.

The distribution of answers about leaders having a sense of empathy high for their subordinates agrees with 90 respondents (60\%), although 2 respondents disagree. The average score of 3.99 indicates that most respondents agree that the leader has a sense of empathy high for subordinates. In addition, the average score of Idealized Influence is 4.01, which means that respondents tend to agree if the leader has extensive knowledge.

The distribution of respondents' answers on the leadership aspect encouraged lecturers to improve the quality of education; most of them agreed with 85 respondents $(56.7 \%)$. The average score of 4.11 indicates that respondents tend to agree that leaders encourage lecturers to improve the quality of education.

The distribution of respondents' answers on the leadership aspect appreciated the lecturers' achievements; most of the respondents agreed that 75 respondents $(50 \%)$. In addition, the average score of 3.78 shows that respondents tend to agree that the leader appreciates the lecturers' achievements.

The distribution of respondents' answers on the aspect of leaders giving awards to outstanding lecturers stated that the respondents who agreed were 79 people $(52.7 \%)$. The average score of 3.62 shows that respondents agree that leaders give awards to lecturers who excel. 
Distribution of respondents' answers The leader encourages lecturers to be creative in carrying out learning shows that most of the respondents stated that they were neutral by 88 respondents $(58.7 \%)$, although there were 2 respondents (1.3\%) who disagreed. The average score of 3.99 indicates that most respondents agree that the leader encourages lecturers to be creative in learning.

Distribution of respondents' answers The leader encourages lecturers to develop innovation in learning. Most of the respondents agree with 60 respondents $(40 \%)$, although 5 respondents $(3.3 \%)$ disagree. The average score of 3.53 indicates that respondents tend to agree that leaders encourage lecturers to develop innovations in learning.

Distribution of respondents' answers On the aspect of the leader, he is very respectful of the lecturers' ideas, which shows that most of the respondents agree that 80 respondents $(53.3 \%)$. Furthermore, the average score of 3.76 indicates that respondents agree that the leader is very respectful of the ideas conveyed by the lecturer.

Distribution of respondents' answers in leadership providing convenience to lecturers to increase academic positions as many as 89 respondents agreed $(59.3 \%)$, although 2 respondents disagreed $(1.3 \%)$. The average score of 3.99 indicates that respondents agree that the leader provides facilities for lecturers to improve academic positions. Furthermore, the average score of the indicator is Inspirational Motivation 3.82, which means that respondents tend to agree if the leader encourages lecturers to improve the quality of education.

The distribution of respondents' answers on the aspect of leadership encouraging lecturers to be creative in completing work shows that most of the respondents agree with 70 respondents $(46.7 \%)$, although 3 respondents (2\%) disagree. The average score of 3.74 indicates that respondents agree with leaders encouraging lecturers to be creative in completing work.

The distribution of respondents' answers to leaders encourages lecturers to always be innovative in completing work, indicating that most respondents agreed with 88 respondents $(58.7 \%)$. Furthermore, the average score of 3.96 shows that respondents agree with leaders encouraging lecturers to always be innovative in completing work.

The distribution of respondents' answers about leaders always asking for input from lecturers in making decisions shows that most of the respondents agreed with 85 respondents $(56.7 \%)$. The average score obtained is 4.05 , which shows that most of the respondents agree that the leader always asks for input from the lecturer in making decisions.

The distribution of respondents' answers about solving problems the leader always looks for the root of the problem from various points of view shows that most of the respondents agree as many as 72 respondents (48\%), although there are 7 respondents $(4.7 \%)$ who disagree. The average score of 3.82 indicates that most respondents agree that the leader in solving problems always looks for the root of the problem from various points of view.

The distribution of respondents' answers about leaders who are always enthusiastic in listening to ideas conveyed by lecturers shows that most of the respondents agreed as many as 66 respondents (44\%), although there was 1 respondent (0.7\%) who disagreed. The average score obtained is 4.01 , which shows that most of the respondents agree that the leader is always enthusiastic in listening to the ideas conveyed by the lecturer.

The distribution of respondents' leaders encourages faculty to solve problems rationally work indicates that the majority of respondents agreed as many as 64 respondents $(42.7 \% \%)$. However, one respondent $(0.7 \%)$ disagreed with the average score of 4 .02 , which shows that most of the respondents agree that the leader encourages subordinates to solve work problems rationally. The average score of the indicator is Intellectual Stimulation 3.93, which means that the respondents agree that the leader always asks for input from the lecturer in making decisions.

The distribution of respondents' answers about the leader always tries to improve the lecturer's self-development. Most of the respondents agree with 82 respondents $(54.7 \%)$, although there is 1 respondent disagrees $(0.7 \%)$. The average score of 3.75 shows that most respondents agree that the leader always tries to improve the lecturer's self-development.

The distribution of respondents' answers about leaders treating lecturers as private individuals, not just as members of a workgroup Most agree 84 respondents (56\%). The average score is 4.03 , which shows that most respondents agree that the leader treats lecturers as individual lecturers; it is appropriate not only as members of the workgroup.

Distribution of respondents' answers about leaders willing to listen to the difficulties and complaints experienced by lecturers. Most of them agreed with 81 respondents (54\%). The average score is 3.97 , which shows that respondents agree that a leader is willing to listen to the difficulties and complaints experienced by lecturers.

The distribution of respondents' answers about leaders advising lecturer self-development obtained the most answers agreeing as many as 83 respondents (55.3). The average score is 3.97, which shows that most respondents agree that the leader advises the lecturer's self-development.

The distribution of respondents' answers about leaders understanding the strengths and weaknesses of each lecturer mostly agreed with 80 respondents $(53.3 \%)$. The average score is 3.81, which shows that most of the respondents agree that the leader understands the strengths and weaknesses of each lecturer and is very wise. The average score of the indicator is Individual Consideration 3.90, which means that most respondents agree that the leader treats lecturers as private individuals, not just as members of a workgroup.

Overall, the average score of transformational leadership style is 3.91, which means that respondents agree that transformational leadership style is formed from idealized influence, inspirational motivation, intellectual stimulation, and 
individual consideration. The most significant contribution to forming a transformational leadership style is idealized influence, which is reflected in the leader's extensive knowledge. The low contribution in the formation of transformational leadership style is inspirational motivation.

\section{b. Description of Professionalism Variable (X2)}

Indicators of Professionalism variable as shown in the table measure 4 indicators, namely Pedagogic Competence, Professional Competence, Personality Competence, and Social Competence. The frequency distribution of the Professionalism variable is obtained from the results of the tabulation of the respondents' answer scores as presented in Table 8 .

Based on Table 8, it can be seen that from the distribution of respondents' answers on the aspect of ability in readiness to provide material as well as the suitability of test material and assignments with course objectives, most of them agree. 79 respondents $(52.7 \%)$. The average score is 3.60 , which indicates that the respondents agree that the lecturer can be ready to provide material and the suitability of the test material and course objectives.

The distribution of respondents' answers on aspects of the orderliness and orderliness of lectures is primarily neutral, 60 respondents $(40 \%)$, although there are 10 respondents $(6.7 \%)$ who disagree. The average score of 3.40 indicates that most of the respondents are neutral towards the regularity and orderliness of the lectures.

Distribution of answers on the aspect of livening up the classroom atmosphere and providing feedback on assignments. Most of the respondents stated that they were neutral, 75 respondents $(50 \%)$ although 5 respondents $(3.3 \%)$ disagreed. Average score 3.50. This shows that respondents tend to be neutral and can liven up the classroom atmosphere and provide feedback on assignments.

Distribution of respondents' answers on the aspect of Clarity in conveying material and answers to questions in class Most agree 82 respondents $(54.7 \%)$. The average score is 4.01 . Shows respondents tend to agree that respondents can convey material and answers to questions in class.

Distribution of respondents' opinions on the ability to use media and learning technology, most of them agreed with 82 respondents $(54.7 \%)$. The average score of 4.01 indicates that respondents tend to agree that respondents can use learning media and technology.

The distribution of respondents' answers on the aspect of diversity in measuring learning outcomes and the suitability of the values given with learning outcomes Most of them agreed with 82 respondents $(54.7 \%)$. The average score of 4.01 indicates that respondents tend to agree with the diversity of measuring learning outcomes and the suitability of the values given to learning outcomes.

The average score of the pedagogical competency indicator is 3.75, which means that most respondents agree that Clarity conveys material and answers questions in class, can use learning media and technology, and diversity in measuring learning outcomes and the suitability of the values given with the results. Study.

The distribution of respondents' answers on the ability to explain the subject/topic correctly. Most of them agreed with 78 respondents $(52 \%)$. The average score of 3.88 indicates that respondents agree that the lecturer can explain the subject/topic appropriately.

Distribution of respondents' answers on the ability to provide relevant examples of the concepts being taught Most agreed 89 respondents $(59.3 \%)$. The average score of 4.03 indicates that respondents tend to agree that the lecturer can provide relevant examples of the concepts that have been taught to students.

Distribution of respondents' answers on the ability to explain the relevance of the field/topic being taught with other fields/topics and the context of life. Most of them agreed with 84 respondents (56\%). The average score of 4.07 indicates that respondents agree that the lecturer can explain the relevance of the field/topic being taught with other fields/topics and the context of life.

Distribution of respondents' answers on mastery of the latest issues in the field being taught. Most agreed with 82 respondents $(54.7 \%)$, although 1 respondent $(0.7 \%)$ disagreed. The average score of 3.93 indicates that respondents agree that Lecturers can master the latest issues related to the field being taught.

Distribution of respondents' answers on the aspect of using research results to improve the quality of lectures. Most of them agreed with 82 respondents $(54.7 \%)$, although 1 respondent $(0.7 \%)$ disagreed. The average score of 3.91 indicates that respondents tend to agree that the use of research results improves the quality of lectures.

Distribution of respondents' answers on the aspect of the ability to use various communication technologies Most agreed 83 respondents $(55.3 \%)$ although there was 1 respondent $(0.7 \%)$ disagreed. The average score of 3.92 indicates that respondents tend to agree that lecturers can use various communication technologies.

The average score of the professional competence indicator is 3.95, which means that respondents tend to agree that the lecturer can explain the relevance of the field/topic being taught with other fields/topics and the context of life.

Distribution of respondents' answers on authority as a personal lecturer Most of them agreed with 88 respondents (58.7\%). The average score of 3.88 shows that respondents tend to agree that lecturers have authority as lecturers. 
The distribution of respondents' answers on the aspect of wisdom in making decisions. Most of them agreed with 88 respondents $(58.7 \%)$. The average score of 3.97 shows that respondents tend to agree that lecturers are wise in making decisions.

Distribution of respondents' answers on aspects of being an example in attitude and behavior Most of them agreed with 91 respondents $(60.7 \%)$, although 1 respondent $(0.7 \%)$ disagreed. The average score of 4.03 shows that respondents agree that lecturers must be examples in attitude and behavior.

Distribution of respondents' answers on self-control in various situations and conditions Most of them agreed with 85 respondents $(56.7 \%)$. The average score of 3.94 shows that respondents agree that lecturers can control themselves in various situations and conditions.

Distribution of respondents' answers on the fair aspect of treating students Most of them agreed with 85 respondents $(56.7 \%)$. The average score of 3.94 shows that respondents agree that lecturers must be fair in treating students. In addition, the average score of the personality competency indicator is 3.95 , which means that respondents agree that the lecturer is an example of attitude and behavior.

Distribution of respondents' answers on the ability to express opinions Most of them agreed with 90 respondents (60\%). The average score of 4.05 indicates that respondents tend to agree that lecturers can express opinions.

Distribution of respondents' answers on the ability to accept criticism, suggestions, and opinions of others. Most of the respondents agreed with 74 respondents $(49.3 \%)$. The average score of 4.00 indicates that respondents tend to agree that lecturers can accept others' criticism, suggestions, and opinions.

The distribution of respondents' answers on the aspect of knowing well the students who attended the lectures. Most of them agreed with 80 respondents $(53.3 \%)$. The average score of 3.89 indicates that respondents agree that lecturers must know the students who attend lectures well.

Distribution of respondents' answers on sociability among colleagues, employees, and students Most of them agreed with 84 respondents $(56 \%)$, although 1 respondent $(0.7 \%)$ disagreed. The average score of 4.02 shows that respondents agree that lecturers quickly get along with colleagues, employees, and students.

Distribution of respondents' answers on the aspect of tolerance for student diversity. Most of them agreed with 84 respondents $(56 \%)$, although 1 respondent $(0.7 \%)$ disagreed. The average score obtained in this aspect is 4.02 , indicating that respondents agree that lecturers must be tolerant of student diversity. In addition, the average score of the Social competence indicator is 4.00, which means that respondents agree that lecturers can express opinions.

Overall the average Professionalism score is 3.91, which means that respondents agree that professionalism is formed from pedagogic competence, professional competence, personality competence, and social competence. The most significant contribution to the formation of professionalism is social competence which is reflected in expressing opinions. The low contribution in the formation of professionalism is pedagogic ability.

\section{CONCLUSION}

From the results of the discussion that has been carried out, it can be concluded as follows: Transformational leadership style is formed from Idealized influence: inspirational motivation, intellectual stimulation, and individual consideration. The most significant contribution to forming a transformational leadership style is idealized influence, which is reflected in the leader's extensive knowledge. The professionalism formed from Pedagogic Competence, Professional Competence, Personal Competence, and Social Competence, the most significant contribution is Social competence, which is reflected in the ability to express opinions.

For Higher Education Leaders as policymakers in educational institutions, The results of this study can be used as an illustration in preparing a plan for developing human resources (lecturers) so that the performance of each lecturer can be improved.

\section{REFERENCES}

1. Anung Pramudyo. 2010. Analysis of Factors Affecting the Performance of State Lecturers at Kopertis Region V Togyakarta. Vol.1, No. February 1, 2010.

2. Harmen, H., \& Amanah, D. 2013. Analysis of the Organizational Commitment Model on the Performance of Lecturers at the State University of Medan. Journal of Finance \& Business, 5(3), 205-213.

3. Haryati, Sri. 2013. The Educational Profession Guide for Teachers and Teacher Candidates, Yogyakarta: Nine Stars Publisher. 
International Journal of Advances in Scientific Research and Engineering (ijasre), Vol 7 (9), September -2021

4. Robbin, S. 2008. Organizational Behavior, Volumes I and II, Translation: Hadyana Pujaatmaja, Jakarta, Prenhallindo

5. Robbins, Stephen P., \& Coulter, M. A. 2012. Robbins \& Coulter, Management Pearson (11th ed.).

6. Rorimpandey, L. 2013. Transformational, transactional, situational, service and authentic leadership styles on the performance of sub-district employees in Bunaken sub-district, Manado city. EMBA Journal, 1(4), 2233-2244.

7. Wijayanto, D. 2012. Introduction to Book Management. Digital Gramedia. 